\section{RESEARCH IN MEDICINE.}

THE object of research is to discover something which was not previously known, or to correct or to confirm some previous observations. There are two methods of research-one by observation, the other by experiment. In medical research the method by observation is much out of fashion; it is slow, and may be often interrupted for want of material. The imperfection of the material is often very disappointing. The method by experiment (not by any means limited to experiments on animals), on the other hand, is the fashion of the day; it is quicker, less liable to be interrupted, and may yield brilliant results in a very short space of time. But it is a two-edged weapon, and needs to be used, and its results to be accepted, with great caution. Mr. Hunter, who was a confirmed and most ingenious experimenter, said in the course of his evidence at the trial of Captain Donellan :"I apprehend a great deal depends upon the mode of experiment; no man is fit to make one but those who have made many and paid attention to all the circumstances that relate to experiments."

Let me give you my experience of the two methods in the investigation of cancer. Many years ago there was great confusion in the minds of pathologists and surgeons regarding the differences and resemblances between sarcoma and carcinoma. I made a diligent study of them by observation of the cases at my hospital, the cases at other hospitals, and the cases recorded in the literature of many countries. The research was very long, very tedious, and very disappointing by reason of the small number of cases which were sufficiently recorded to be available for use. The results formed the subject of the Erasmus Wilson lectures thirty years ago, and proved that the life-history of the varieties of malignant disease does not depend merely on their structure, but upon their seat of origin, and that the varieties of malignant disease of every part of the body must be separately studied if they are to be treated with success. Observations of a similar kind have been made by other clinical pathologists, with the result that the most successful operations for cancer at the present time are based on the results of clinical pathology. For no part of the body has this been done with greater success than for the breast. Charles Moore and Mitchell Banks urged the importance of very large operations many years ago but surgeons fought shy of them, because they lacked that which was supplied many years later by Heidenhain and Styles-a scientific basis. Recently Handley has again added valuable information on the same subject, founded on clinical and microscopical observation.

I have never engaged personally in experimental investigation on account of the difficulty of doing so thirty years ago. But I have been associated with the Imperial Cancer Research, and in touch with its staff from the foundation of the research, and have been a member of the publication committee of all its scientific reports. It has done nothing on the lines in which observation has been so useful. It has not unfolded the life-history of a single variety of cancer so that we can base our operations on the information. It has not even discovered whether spontaneous cancer of a particular part of the body in the rat or mouse runs a similar course to spontaneous cancer of the same part of the body in the human subject. These problems are not suited for experimental investigation; they are determined by observation. On the other hand within the space of eight or ten years it has definitely settled a matter of dispute which was discussed and fought long before I became a student, perhaps for centuries. It has proved, beyond the possibility of doubt, that cancer in its early stages is a local, not a constitutional or blood, disease. It is impossible to overrate the value of this knowledge to the surgeon. So long as he believed that cancer is in the blood, and that an operation only removes the local manifestation of it, he was hopeless of the results of his operations, and removed the tumour solely to afford the patient temporary relief. Now he goes to his operation filled with hope that, if the disease is limited and in an early stage, and his operation is well designed and skilfully carried

I From the introductory address delivered at the opening of the winter ession, Ortober 2, at the London School of Medicine for Women, by Sir Henry T. Butlin, Bart.

NO. 2 I 88 , VOL. 87] out, it may be quite successful. Thus it will be seen that the two methods, observation and experiment, have their special values in relation to cancer, that each is supplementary to the other, and that neither is fitted to take the place of the other.

It will be noticed that I have dwelt on the use to which these researches have been put in the treatment of cancer and of the value of them to human beings. You may fairly think these ought to be the immediate objects of all research in medicine, and that researches which are not likely to be immediately useful should be discouraged. But while I freely admit that my sympathy is in favour of this view, I am bound also to admit that it is wholly erroneous. The investigator should be solely interested in discovering the truth, and his attention should not be diverted and his judgment warped by the desire that his research should terminate in a particular manner because that might seem likely to be more useful to medicine and surgery. It is notorious that some of the researches which have seemed to fulfil no useful purpose have yielded the most valuable practical results, while other researches, pursued with a useful end in view, have furnished nothing good. If a utilitarian value were considered essential to research, many voung investigators who have later produced the most brilliant work would have been discouraged, so that they might never have persevered in original research. I need only give two illustrious examples, Pasteur and Lister. ${ }^{1}$ Their first researches had no utilitarian object. What a lamentable thing it would have been if they had been discouraged from research on that account. The great thing is that young people who are fitted to do so should be encouraged to search. What they search for is of comparatively small consequence. On the other hand, I would not have it supposed that a utilitarian research is derogatory to the dignity of the worker or necessarily damages his moral. Sir Humphry Davy deliberately worked out the problem of coal gas and explosions, and invented a safety-lamp at the urgent request of the coal-owners. Pasteur investigated the nature of the Pébrine disease of silkworms at the request of Dumas, and moved by pity at the wretched condition into which the silkworm industry had fallen. He discovered that it depended on a parasitic protozoon, and devised a successful method of stamping it out.

Just a few words on the cost of research. Dr. Leonard $\mathrm{Hill}^{2}$ pointed out some years ago what great results could be achieved by an able worker with the simplest materials and at the smallest cost, and that fine laboratories and costly apparatus are not essential to research in medicine. All this is very true, just as it is true that David killed Goliath with a stone cunningly hurled from a sling. I do not think David at the present day would sally forth with a sling to oppose a foreign host; and our profession is continually urging on the wealthy public the financial claims of research.

In order to determine whether women are likely to be useful and successful in research, it is necessary to consider the qualities which should be looked for in an investigatorI mean in an investigator who has the sole charge of a research, even though it be carried out in a laboratory where other persons are at work. I am not speaking of an expert assistant or even of a joint investigator.

For (I) experimental research (including experiments on animals) I should set down : dexterity and neatness in manipulation; a knowledge not only of the principles, but of the practice, of aseptic and antiseptic surgery; and certainly humanity, so that the experiments which are necessary should be performed with as little suffering to the animals as possible.

For (2) every kind of research I should look for personal cleanliness; cleanliness of habit; industry, which must be extended to mean continued industry; patience, and a large stock of it; perseverance, and a determination to pursue

1 The first re:earches of Pasteur were on the crystalli sation of tartaric acid and its salte. The first researches of Lister were on the contractile tissue of the iris and on the muscular tissue of the skin.

2 Brit. Med.Jour, roo7, vol. i., p. u6o. "Men of science are not made by institutes, money, or apparatus. Helmholtz did his best work on $\mathrm{r} 2 \mathrm{O}$. a year, and modelled his inventions out of snectacle lenses and his wife's sewing gear. Faraday did his epoch-making work with bits of wood, glass, and wire. Claude Bernard filled his pupils with enthusiasm in a laboratory little better than a cellar." 
the research to the end; extreme care in observation and strict attention to detail; careful recording of observations, which should be done at the earliest possible moment; thorough belief in the importance of the particular research, amounting even to enthusiasm; conscientiousness.

Many of these desirable qualities will at once commend themselves to you; they need no more than enumeration. But you may wonder why I have set down others of them. For instance, what has conscientiousness to do with research any more than it has to do with any other of the affairs of life? Do I mean that an investigator should be honest and not appropriate or use unfairly the work of other investigators? Oh, no! I assume such honesty as this in every investigator. The conscientiousness of which I speak is of the worker to himself and his own work. In this way. A worker has been engaged in a research during many months. He has made many experiments and observations, and they have all gone to prove the correctness of the result at which he has arrived. But there is still one experiment which it would be well to try. $\mathrm{He}$ tries it, and curiously it does not turn out quite right. He puts two and two together and they do not make four. And everyone agrees with "The Professor in the Case" that two and two do make four, "not some times, but all the time." Now is the moment when his conscientiousness should come into play. The temptation is overwhelming to explain the failure by some fault in technique, and to set the result of that experiment on one side rather than to repeat it again and again as he ought certainly to have done. Had he done so it would again have failed, and he would have learned in the end, not that two and two do not make four, but that one of his twos was not a two, and he would have avoided publishing that result of his research which was afterwards discovered to be incorrect by a more careful and conscientious worker. It must always be borne in mind that the mischief of a faulty result does not end with that research, but may be the starting point of a long series of equally faulty results.

\section{GEOGRAPHY AT THE BRITISH} ASSOCIATION.

I $\mathrm{N}$ his presidential address Colonel Close, the recently appointed Director-General of the Ordnance Survey, raised again the oft-debated question, "What is geography?" His contention that geography, apart from cartography, cannot be treated as a science in itself, but must serve as a common meeting-place and popularising medium for various other sciences, will certainly not be accepted by modern geographers without considerable modification and amplification.

Prof. Herbertson exhibited and explained a new series of thermal maps which he has constructed to show the actual mean temperatures prevailing over the globe instead of the temperatures reduced to sea-level, as indicated on the ordinary meteorological maps. Among other papers on cartography were two by Mr. A. R. Hinks, one dealing with the use of colour on contour maps, and the other with the most suitable projections for atlas maps. Captain Henrici discussed the present state of our knowledge-not altogether satisfactory-of the mean sea-level round our coasts, and arrived at the conclusion that there is no evidence, from the observations made, to justify the belief that mean sea-level is not constant around the British Isles. Captain Henrici also contributed a note on the height of Ruwenzori as determined by him from observations made by Captain Jack. His result is $\mathrm{I} 6,8 \mathrm{O} \mathrm{I} \cdot 3 \pm 5 \cdot 3$ feet.

Among the papers on physical geography, two of the most interesting were contributed by Prof. J. W. Gregory and Prof. O. Pettersson. The former showed that while waterfalls have generally been regarded as destructive, they may in certain circumstances be constructive and act as agents of deposition instead of denudation. In support of this he instanced certain waterfalls in Dalmatia, Bosnia, and Herzegovina. In the former country, for example, the Kerka Falls are due to a barrier of calcareous tufa which the Kerka River has built across its valley. Prof. Pettersson discussed the deep-water movements in the Skagerrak, and showed that they occurred when the earth

NO. 2 I 88 , VOL. 87 ] is in perihelion. His theory is that these waves are in fluenced by the phases of the moon, but still more by its declination and distance from the earth. $\mathrm{He}$ also showed that since 1753 the herring fishery on the coasts of Sweden has been most prolific in years of maximum declination and least prolific in years of minimum declination, a resuit which he attributes to the influence of the movements in the deep water. Captain Rawling gave an account of the British expedition to Dutch New Guinea, and showed some excellent views of the Nassau Range with its precipitous front more than eighty miles in length and from 8000 to 10,500 feet in sheer height.

The work of the section was concluded by an interesting discussion on aëronautical maps. M. Lallemand described the resolutions recently adopted at his suggestion by the Permanent Committee for Aërial Navigation of the Public Works Department of the French Government on the production of an international air-map, and the establishment of marks required by aviators and aëronauts. Captain Lyons followed with certain general suggestions for the construction of aëronautical maps, and in the subsequent discussion several officers of the air battalion and others took part. A full report of this discussion is to be published in The Geographical Journal.

\section{MECHANICAL SCIENCE AT THE BRITISH ASSOCIATION.}

THE meeting of the Mechanical Science Section of the British Association at Portsmouth, under the presidency of so distinguished a naval architect as Prof. Harvard Biles, was naturally the occasion for a very interesting programme of papers relating to many branches of marine engineering work ranging over a wide field of applied science, and dealing with some of the most important developments which are now engaging the attention of engineers and men of science in this branch of engineering activity.

The programme contained important papers on the rolling of ships, by the president, the gyro-compass, electrical steering and propulsion of ships, and the developments of wireless telegraphy, especially in its relation to naval problems; while in the purely mechanical section the advances in methods of generating motive power were dealt with in a series of related papers on internal-combustion engines and the superheated steam engine. Not only had the members who attended this section an opportunity of hearing these papers and the very interesting discussions to which they gave rise, but all the sections took the opportunity so kindly afforded them by Admiral Sir A. W. Moore of witnessing, from a battleship which carried them into the Solent, a combined attack by numerous torpedoboats and submarine vessels with as near an approach to the conditions of naval warfare as practicable.

The interest which all members of the association take in the practical applications of scientific discovery to naval matters was manifested by the close attention to the wonderful evolutions and diving performances of the attacking vessels, while the swift and silent attack of the torpedoes, invariably marked by the final dull thud of impact as each one found its mark, gave a thrill of the possibilities of actual warfare not easily forgotten.

Although the proceedings of the section were so largely devoted to naval matters, other subjects of importance also claimed the attention of the members, like the non-stop train, the peculiar corrugations produced on rails by the long-continued passage of trains; while subjects of more general interest were afforded by papers on smoke abatement, and the possibilities of the manufacture of nitrogen products in this country by electric power, a question of great importance in connection with agriculture and the manufacture of explosives.

The discussion between Sections A and G on aërial flight at the Monday's meeting attracted a very large gathering, and has been dealt with in a separate article (September 28 , p. 439).

We now turn to a more detailed examination of the papers in their order, and the discussions to which they gave rise. The president's address, on the rolling of ships, 